\title{
EFFECT OF ATTITUDES, NORMS, AND PERCEPTION OF CONTROL OF FOOT CARE BEHAVIOR IN PATIENTS DIABTES MELITUS IN SURABAYA CITY
}

\author{
Nuh Huda ${ }^{1 *}$, Dhian Satya ${ }^{2}$, Yohana Novitasari Sutrisno ${ }^{3}$ \\ Email*: badawiff@gmail.com \\ 1,2,3 College of Health Sciences Hang Tuah Surabaya
}

\begin{abstract}
s
Introduction:Each year the incidence of diabetes has very Significantly Increased. Increased risk of foot injuries are the caused because people have attitudes, norms, and perceptions of less control over his foot care. This study Identifies and analyzes the influence attitudes, norms, and perceived control over behavior treatment in DM Patients foot. Methods: The study used observational analytic design with cross sectional approach at a time. The study population as many as 50241 people as calculated using the technique of Cluster Obtained 185 samples diabetics. This study uses probability sampling cluster sampling approach with analysis of the Chi Square test. Intsrument questionnaire used in this research and Foot Care Behavior TPB questionnaire the which has been tested for validity and reliability. Results: Based on statistical analysis Obtained attitude towards foot care behaviors value $=0.001 \rho(\rho<0.05)$, the norm of the behavior of foot care $\rho$ value value $=0.001(\rho<0.05)$, perceived behavioral control of foot care value $\rho$ value $=0.001(\rho<0.05)$ so that we can conclude the influence attitudes, norms, and perceived behavioral control in Patients with diabetic foot care. Conclusions: Foot care was right and good behavior will prevent foot ulcers in diabetic patient. Patients DM was expected to know, willing, and Able to perform behavioral treatments for further enhanced, so that people Become aware, willing and Able to do foot care behavior.
\end{abstract}

Keywords: behavioral foot care; diabetes mellitus; theory of planned behavior

\section{INTRODUCTION}

Diabetes Mellitus become one of the health problems noticed by the world. Each year the incidence of diabetes mellitus has increased very significantly in the world, including in developing countries such as Indonesia also increased(Ministry of Health, 2014), The increasing number of health problems is because many people or patients with diabetes mellitus are indifferent and do not care about his health. Factors that cause diabetes mellitus and leg injuries are peripheral neuropathy, vascular disorders, poor blood sugar control, repetitive trauma, and abnormal anatomical structures (Windani, Sari, Haroen, and Padjadjaran, 2016). Patients with diabetes mellitus who suffered leg injuries each year increased, the study noted that every patient with diabetes mellitus will have one foot exposed to injuries (Arianti, 2015).

World Health Organization (WHO) estimates that the number of patients with diabetes mellitus worldwide by 2015 as many as 415 million people and estimates that by 2040 the number of patients with diabetes mellitus will increase to 642 million. Diabetes mellitus occurs 10 years earlier in South East Asia rather than Europe. Patients with diabetes mellitus in Indonesia in 2015 was ranked seventh in the world along with China, India, United States, Brazil, Russia, and Mexico, with a total of 10 million inhabitants. Patients with diabetes mellitus are located in Surabaya, according to data from Surabaya city health department in 2018 as many as 199104 people. Data amounts to 50241 patients with diabetes mellitus were enrolled in the clinic the southern city of Surabaya.

Based on the data obtained prevalence of age affected or diagnosed diabetes mellitus at age $\geq 15$ years (RISKESDAS, 2018). The occurrence of foot wounds in diabetics because there are still many who do not understand the importance of foot care and proper application. Many people are still not able or not to apply every day(Arianti, 2015). Patients with diabetes mellitus who understand the importance of foot care only $10 \%$ of people only understand how to choose proper footwear such as select shoes that are not too small or too big, to examine the circumstances foot skin or keep the feet remain moist still many who do not know or apply (Windani, Sari, Haroen, and Padjadjaran, 2016).

One of the preventive measures taken is by foot care Diabetes Mellitus. Foot Care Diabetes Mellitus rated easy and can be done by people with diabetes mellitus independently. Although considered to be easy to do but there 
are still many patients with diabetes mellitus who are not running or appropriate to apply the expected foot care (Windani, Sari, Haroen, and Padjadjaran, 2016). Based on the description above, the researchers want to improve attitudes, norms, and perceptions of control patients for more attention to foot care behavior. Researchers will take the title Influence Attitudes, Norms, Perceived Control of Foot Care Behavior in Patients Diabeates Mellitus in South Surabaya City area.

\section{METHODS}

The technique design in this result using probability sampling. Cluster sampling using a sampling of 185 diabetics melitus registered in South Surabaya city area health centers. Data obtained by TPB questionnaire instrument have a received permission and have a modified questionnaire (Lilis, 2016) and questionnaire foot care practices instrument have a received permission and have a modified questionnaire (Senussi, Lincoln, \& Jeffcoate, 2014). The analysis in this study using the Chi-Square. This study had ethical approval and the approval of some of the parties concerned. Number persetujuanPE / 36 / V / 2019 / KEPK / SHT. Criteria for inclusion in this study for patients with diabetes mellitus registered in South Surabaya city area health centers and patients aged $\geq 15$ years. Exclusion criteria in this study for patients who resist being patient.

\section{RESULTS AND DISCUSSIONS}

1. Characteristics of patients based on their attitude in people with diabetes mellitus in the clinic area south of Surabaya city on the 16th of May - 2 June 2019 with the number of 185 patients

Table 1

\begin{tabular}{ccc}
\hline Attitude & $\begin{array}{c}\text { Frequency } \\
(\mathrm{f})\end{array}$ & $\begin{array}{c}\text { Percentage } \\
(\%)\end{array}$ \\
\hline High & 178 & $96.2 \%$ \\
Low & 7 & $3.8 \%$ \\
\hline Total & 185 & $100 \%$ \\
\hline
\end{tabular}

In general, the results of research that has been done in the clinic area south of Surabaya city in accordance with the specific data in Table 1 shows the results of most patients with diabetes mellitus have a high attitude as many as 178 people (96.2\%), and patients with diabetes mellitus who have a low stance 7 people $(3.8 \%)$.
Attitudes can be defined as a response that will arise when individuals are faced with a stimulus or a situation that gives a response or action through experiences that affect directly or indirectly and being an evaluation of feeling (Notoatmodjo, 2012).

According to the results of the analysis of researchers, from 185 patients there were 178 $(83.2 \%)$ who have a high attitude. Researchers concluded and assume that patients who have a high attitude due to several factors: age and education, the adult person's age and the higher one's education it will be more prudent in attitude. The assumption of researchers supported by another study by Ainal Mardhiah said that age and education can affect a person's attitude, the older or more mature age of a person, the more skilled and more information is obtained and the higher one's education, the better their mindset in digesting the information which may underlie the person's pattern of behavior so that they can understand which actions should be done and not done (Ainal, 2013).

According to the results of the analysis of researchers, from there 7orang 185 patients (3.8\%) who had low attitude. Researchers assume less patient gets the correct information about perawtaan feet, it is supported from the patient questionnaire results not agree with how to cut toenails straight line, and after a shower. Assumptions of researchers supported by another study by Aminatul that attitude and a good knowledge not necessarily produce a good attitude as well as attitude has several levels based on its intensity, in-depth knowledge on a matter will memningkatkan intensity of attitude, then the intensity of the high attitude will affect a person to behave in accordance with attitude(Aminatul, 2016).

2. Characteristics of patients based on the norm in patients with Diabetes Mellitus in community health centers southern region of the city of Surabaya on 16 May - 2 June 2019 with the number of 185 patients.

Table 2

\begin{tabular}{ccc}
\hline Norm & $\begin{array}{c}\text { Frequency } \\
\text { (f) }\end{array}$ & $\begin{array}{c}\text { Percentage } \\
(\%)\end{array}$ \\
\hline High & 181 & $97.8 \%$ \\
Low & 4 & $2.2 \%$ \\
\hline Total & 185 & $100 \%$ \\
\hline
\end{tabular}

In general, the results of research that has been done in the clinic area south of 
Surabaya city in accordance with the specific data in Table 2 shows the results of the norm in patients with diabetes mellitus with the number of 185 patients, the majority of patients with diabetes mellitus have a higher norm as many as 181 people $(97.8 \%)$ and patients with diabetes mellitus who have lower norm of 4 people $(2.2 \%)$.

Subjective norm can be interpreted as a belief that is influenced by other people deemed important by individuals who advise the individual to perform or not perform certain behaviors and motivation coupled with a willingness to do or not do something that is considered important (Whida, 2017).

According to the results of the analysis of researchers, from 185 patients there were 181 people $(97.8 \%)$ who have a high norm. According to the results of cross tabulation researchers assume that patients whose age adults can receive input or opinion of the surroundings or the environment, the better the environment is getting much support or advise patients to take better care of the feet. Assumptions of researchers supported by Uway Warriah another study says that social influences can affect a person's norm behave as expected, a person will have a desire to an object or behavior, influenced by the people around him to do or manyakini that environment or those people around support to what is done(Uway, 2011).

According to the results of the analysis of researchers, from 185 patients there were 4 (2.2\%), which has a low norm. According to the results of cross tabulation researchers assume that patients aged 36-45 years old and suffering from diabetes for less than 2 years is still not getting the proper social support, social support maksut of this is the notion of family or friends, the patient is not getting social support is greater than the surrounding so people still do not perform routine foot care. Additional research assumptions of researchers supported by Gilang Dwi Prakoso and Fatah called the analysis of the influence attitudes, behavior control, subjective norms on behavior and safety that the encouragement of the environment around the patient will affect or not affect those with diabetes mellitus in foot care behavior (Prakoso and Fatah, 2017).

3. Characteristics of patients based on the perception of control in patients with diabetes mellitus in the clinic area south of Surabaya city on the 16th of May - 2
June 2019 with the number of 185 patients.

Table 3

\begin{tabular}{ccc}
\hline $\begin{array}{c}\text { Perception } \\
\text { Control }\end{array}$ & $\begin{array}{c}\text { Frequency } \\
(\mathrm{f})\end{array}$ & $\begin{array}{c}\text { Percentage } \\
(\%)\end{array}$ \\
\hline High & 179 & $96.8 \%$ \\
Low & 6 & $3.2 \%$ \\
\hline Total & 185 & $100 \%$
\end{tabular}

In general, the results of research that has been done in the clinic area south of Surabaya city in accordance with the specific data in Table 3 shows the results, most patients with diabetes mellitus high perception of control as many as 179 people (96.8\%) and patients with diabetes mellitus a low perception of control as $6(3.2 \%)$.

Perception of control is determined role in the form of self-efficacy is a condition where people believe that the behavior is easy or difficult to do (Machrus 2010; whida, 2011).

According to the results of the analysis of researchers, from 185 patients there were 179 people $(96.8 \%)$ who have a high perception of control. Based on the results of cross tabulations researchers assume that patients who suffer from diabetes mellitus is more than 2 years has been able to do foot care behavior because people want to minimize the risk of leg injuries. This assumption is supported by other studies that Iga Trimurthy that perception can be seen or perceived control to determine the wishes, meant that the higher the perception of control will increase the desire to use the products offered (Iga, 2009).

According to the results of the analysis of researchers, from 185 patients there were 6 (3.2\%) who have a low perception of control. Based on the results of cross tabulations researchers assume that people are still suffering less than 2 years is still have less control because the perception of the patient felt perception in itself is not enough to do foot care behavior. This assumption is supported by other studies Isaac said that the perception of control a person's perception of a behavior that other people do, where the person of the behavior owned believed that the result of the control itself(Isaac, 2015).

4. Characteristics of patients based foot care behaviors in patients with Diabetes Mellitus in community health centers southern region of the city of Surabaya on 16 May - 2 June 2019 with the number of 185 patients.

Table 4 


\begin{tabular}{ccc}
\hline $\begin{array}{c}\text { behavior } \\
\text { chiropody }\end{array}$ & $\begin{array}{c}\text { Frequen } \\
\text { cy (f) }\end{array}$ & $\begin{array}{c}\text { Percenta } \\
\text { ge }(\%)\end{array}$ \\
\hline High & 185 & $100 \%$ \\
Low & 0 & $0 \%$ \\
\hline Total & 185 & $100 \%$ \\
\hline
\end{tabular}

In general, the results of research that has been done in the clinic area south of Surabaya city in accordance with the specific data in Table 4 shows foot care behaviors in patients with diabetes mellitus with the number of 185 patients, the majority of patients with diabetes mellitus foot care properly perform as many as 119 people $(64.3 \%)$ and patients with diabetes mellitus who do care enough feet in as many as 66 people $(35.7 \%)$, who do care quite as much as 47 feet in person (25.4\%).

Foot care is primary prevention in diabetic foot injury to determine any abnormalities as early as possible, keep feet clean and prevent injuries to the foot of the DAPT raises the risk of infection and amputation (Damayanti, 2017).

According to the results of the analysis of researchers, from 185 patients there were 185 people (100\%), which has a high foot care behavior. Based on the results of cross tabulations researchers assumed that patients who have higher education and are already suffering from diabetes mellitus is more than 2 years already understand how to care for the feet that must be observed to prevent foot injuries by checking the shoes before wearing them, wash your feet, check legs and others. Assumptions of research supported by a study by Renny Wulan Apriliyasari mengataka that health education for patients with mellitus diaebets very effective and can make people anticipate for the occurrence of leg wounds with melakukkan perawatn good and right foot (Renny, 2015).

5. Influence attitudes with foot care behaviors in patients with Diabetes Mellitus in community health centers southern region of the city of Surabaya on 16 May - 2 June 2019 with the number of 185 patients. Table 5

\begin{tabular}{ccccccc}
\hline \multirow{2}{*}{$\begin{array}{c}\text { Attitud } \\
\mathrm{e}\end{array}$} & \multicolumn{4}{c}{ Foot Care Behavior In Diabetes } \\
\cline { 2 - 6 } & \multicolumn{2}{c}{ High } & \multicolumn{2}{c}{ Low } & \multicolumn{3}{c}{ Total } \\
\cline { 2 - 7 } & $\mathrm{f}$ & $\%$ & $\mathrm{f}$ & $\%$ & $\mathrm{~N}$ & $\%$ \\
\hline \multirow{2}{*}{ High } & 17 & 96.3 & 0 & 0 & 17 & 100 \\
& 8 & $\%$ & & $\%$ & 8 & $\%$ \\
Low & 7 & $3.8 \%$ & 0 & 0 & 7 & 100 \\
& & & & & & $\%$
\end{tabular}

\begin{tabular}{ccccccc} 
Total & 18 & \multirow{2}{*}{$100 \%$} & 0 & 0 & 18 & 100 \\
& 5 & & $\%$ & 5 & $\%$ \\
\hline
\end{tabular}

The value of statistical test Chi-Square 0.001 $(\rho<0.05)$

Based on the research that has been done in the clinic area of the city of Surabaya south of 185 patients, showed as table 5 showing most patients with attitude and high foot care behaviors by 178 people $(96.3 \%)$ and patients with diabetes mellitus whose stance is low but high foot care behaviors sebayank 7 (3.8\%).

Based on the results of the statistical test Chi-Square value obtained with the value $\rho=$ 0,001 then it shows that $\mathrm{H} 0$ rejected and $\mathrm{H} 1$ accepted, so statistically obtained no influence attitudes towards foot care behaviors in patients with diabetes mellitus in the clinic area south of Surabaya city.

According to the results of the analysis of researchers, from 185 patients there were 178 (96.3\%) who have a high attitude and behavior of high foot care researchers assume that the patient had been suffering from diabetes mellitus, so people are more concerned about the treatment his feet. Assumptions of researchers supported by the results of the questionnaire that most people choose to agree to do foot care to prevent injury, apart from the results of the questionnaire assumptions peneleiti also supported from demographic data of patients who have been suffering from diabetes mellitus is more than 2 years as many as 161 people (87\% ).(Shaliha and Widiastri, 2013).

According to the results of the analysis of researchers, from 185 patients there were 7 (3.8\%) who had low attitude and behavior of high foot care researchers assume that the patient does not have a good and correct information about foot care so patients do foot care in accordance with what they know it. This assumption is supported by other studies Endang Sutisna Sulaiman said that the information that a person has will affect the behavior or beliefs are going to do, this attitude causes someone has evaluations favorable or unfavorable to him (Sulaiman, 2017).

6 . The influence of the norm with foot care behaviors in patients with Diabetes Mellitus in community health centers southern region of the city of Surabaya on 16 May - 2 June 2019 with the number of 185 patients.

Table 6 


\begin{tabular}{ccccccc}
\hline \multirow{2}{*}{$\begin{array}{c}\text { Nor } \\
\mathrm{m}\end{array}$} & \multicolumn{4}{c}{ Foot Care Behavior In Diabetes } \\
\cline { 2 - 7 } & \multicolumn{2}{c}{ Hellitus } \\
\cline { 2 - 7 } & $\mathrm{f}$ & $\%$ & $\mathrm{f}$ & $\%$ & $\mathrm{~N}$ & $\%$ \\
\hline \multirow{2}{*}{ High } & 18 & 97.8 & 0 & 0 & 18 & 100 \\
& 1 & $\%$ & 0 & $\%$ & 1 & $\%$ \\
Low & 4 & $2.2 \%$ & 0 & 0 & 4 & 100 \\
& 18 & & & $\%$ & & $\%$ \\
Total & 5 & $100 \%$ & 0 & 0 & 18 & 100 \\
& & & $\%$ & 5 & $\%$ \\
\hline
\end{tabular}

The value of statistical test Chi-Square $0.001(\rho<0.05)$

Based on the results of research carried out in the clinic telahg Surabaya city area south of 185 patients, showed as table 6 shows that the patient obtained with the norm and high foot care behaviors as much as 181 people $(97.8 \%)$ and patients with diabetes mellitus were the norm is low but high foot care behaviors sebayank 4 (2.2\%).

Based on the results of the statistical test Chi-Square value obtained with the value $\rho=$ 0,001 then it shows that $\mathrm{H} 0$ rejected and $\mathrm{H} 1$ accepted, so that there is a statistically obtained norms influence the behavior of foot care in patients with diabetes mellitus in the clinic area south of Surabaya city.

According to the results of the analysis of researchers, from 185 patients there were 181 people $(97.8 \%)$ who have a high standard and a high foot care behaviors researchers assumed that in addition to the patient is a good home environment of the patient also receives advice from the health service to do foot care, this assumption is supported by the results of the interview in patients with frequent or regular controls and went to the place of service so that patients do foot care at home. Assumptions of researchers supported by other studies Apriningtyas Gani said that the behavior of a person depends on the surrounding environment and mortal, the better the environment will be good too seseornag behavior and those who are around it will affect or suggest to behave well(Apriningtyas, 2018).

According to the results of the analysis of researchers, from 185 patients there were 4 (2.2\%), which has a low norm and high foot care behaviors researchers assume that people with lack of support from family suggest to take better care of the foot, from the time of the observation portion sufferers are home alone because children work home in the afternoon. Assumptions inididukung also with the results of the questionnaire were mnegatakan mostly less agree that patients receiving the advice of his family. This assumption is supported by other studies Farhatun Siti said that the opinion or social support can affect a person's behavior, the more often families, friends support the increasingly open seseornag also desire to live a healthy life(Farhatun,2013).Influence the perception of control with foot care behaviors in patients with Diabetes Mellitus in community health centers southern region of the city of Surabaya on 16 May - 2 June 2019 with the number of 185 patients.

Table 7

\begin{tabular}{ccccccc}
\hline \multirow{2}{*}{$\begin{array}{c}\text { Perceptio } \\
\mathrm{n}\end{array}$} & \multicolumn{5}{c}{ Foot Care Behavior In Diabetes } \\
Control & \multicolumn{4}{c}{ High } & Low & \multicolumn{2}{c}{ Total } \\
\cline { 2 - 7 } & $\mathrm{f}$ & $\%$ & $\mathrm{f}$ & $\%$ & $\mathrm{~N}$ & $\%$ \\
\hline \multirow{2}{*}{ High } & 17 & 96.8 & 0 & 0 & 17 & 100 \\
& 9 & $\%$ & 0 & $\%$ & 9 & $\%$ \\
Low & 6 & $3.2 \%$ & 0 & 0 & 6 & 100 \\
& 18 & & & 0 & 18 & 100 \\
Total & 5 & $100 \%$ & 0 & $\%$ & 5 & $\%$ \\
\hline
\end{tabular}

The value of statistical test Chi-Square 0.001 ( $\rho$ $<0.05)$

Based on the results of research carried out in the clinic telahg Surabaya city area south of 185 patients, showed as table 7 shows that the patient obtained with the perception of control and high foot care behaviors as many as 179 people (96.8\%) and patients with diabetes mellitus who control the perception of low but behavioral treatments sebayank 6 feet tall (3.2\%).

Based on the results of the statistical test Chi-Square value obtained with the value $\rho=$ 0,001 then it shows that $\mathrm{H} 0$ rejected and $\mathrm{H} 1$ accepted, so that there is a statistically obtained perceptions influence behavioral control of foot care in patients with diabetes mellitus in the clinic area south of Surabaya city.

According to the results of the analysis of researchers, from 185 patients there were 179 people $(96.8 \%)$ who had a perception of high control and high foot care behaviors researchers assume that the patient believes or motivation to do foot care will be spared from injury. This assumption is supported by the results of the questionnaire, most people agree to avoid injuries to the legs by doing foot care every day. The assumption is supported by other studies researcher Nadia Rohmatul Laili said that someone would feel the ease if constituted with 
the intention and the will to something that is good for him(Laili, 2016).

According to the results of the analysis of researchers, from 185 patients there were 6 (3.2\%) who have a low perception of control and a high foot care behaviors researchers assume people still have the perception that less and patients have trouble doing this foot care behavior, this assumption is supported by the results of the questionnaire that most choose not agree because it was already doing good foot care dangat. Assumptions of researchers supported by other studies Sekar Wigati Suprapto said that the perception of behavioral control indicates that the behavior or something done by someone dioengaruhi by how he perceives the level of difficulty or ease to a certain berperilkau(Suprapto, 2017).

\section{CONCLUSIONS}

Based on research data and test results on the discussion is done, it can be concluded a attitude Diabetes Mellitus in the clinic area south of Surabaya city high majority. Norma Diabetes Mellitus in the clinic area south of Surabaya city high majority. Perception of control patients with diabetes mellitus in the clinic area south of Surabaya city high majority. Foot care behavior of patients with Diabetes Mellitus in community health centers south of Surabaya city wilakyah high majority. Attitude Diabetes Mellitus in the clinic area south of Surabaya city chiropody effect on behavior. Norma Diabetes Mellitus in the clinic area of the city of Surabaya south effect on the behavior of foot care. Perception of control patients with diabetes mellitus in the clinic area of the city of Surabaya south effect on the behavior of foot care. For patients with researchers hope patients can apply foot care behaviors in daily life and can prevent and reduce terkana leg injuries.

\section{REFERENCES}

Ainal. (2013). Pendidikan Kesehatan dalam Peningkatan Pengetahuan, Sikap dan Keterampilan Keluarga Dengan Hipertensi.

Aminatul. (2016). Hubungan Umur, Sikap, Sengetahuan, Biaya Terhadap Tindakan untuk Melakukan Operasi Katarak, (September 2016), 176-187. https://doi.org/10.20473/jbe.v4i2.2016.17
6

Apriningtyas, G. (2018). Literasi Kesehatan dan Perilaku pada Remaja : Studi Potong Lintang Berbasis Theory of Planned Behaviour Tentang Sikap, Norma Subjektif, dan Perceived Behavioural control danIntensi Perilaku Merokok. Universitas Gajah Mada.

Arianti. (2015). Hubungan Antara Perawatan Kaki dengan Resiko Ulkus Kaki Diabaetes di Rumah Sakit PKU Muhammadiyah Yogyakarta.

Damayanti. (2017). Diabetes Melitus dan Penatalaksanaan Keperawatan. Yogyakarta: Nuha Medika.

Farhatun, S. (2013). Perilaku Konsumsi Serat pada Mahasiwa Fakultas Kedokteran dan Ilmu Kesehatan (FKIK) Universitas Islam Negeri (UIN) Jakarta. Universirtas Islam Negeri Syarif Hidayatullah Jakarta.

Gilang. (2017). Analisis Pengaruh Sikap, Kontrol Perilaku, dan Norma Subjektif Terhadap Perilaku Safety, 193-204.

Iga. (2009). Analisis Hubungan Persepsi Pasien Tentang Mutu Pelayanan Dengan Minat Pemanfaatan Ulang Pelayanan Rawat Jalan Puskesmas Pandadanaran Kota Semarang.

Ishak. (2015). Persepsi Masyarakat tentang Kualitas Pelayanan Kesehatan Melalui Program Jaminan Kesehatan Melalui Program Jaminan Kesehatan Aceh (JKA) terhadapt Kepuasan Masyarakat Rawat Inap pada Puskesmas Tanah Pasir Kabupaten Aceh Utara.

Kementrian Kesehatan RI. (2014). Pusat Data dan Informasi. Jakarta: Infodatin Pusat Data dan Informasi Kesehatan Kementrian RI.

Lilis. (2016). Aplikasi Teori Perilaku Berencana (Theory of Planned Behaviour) Sesehatan Reproduksi Remaja di SMU negeri Karanganyar. Universitas Sebelas Maret Surakarta.

Machrus, H. U. P. (2010). Pengkuran Perilaku berdasarkan Theory of Planned Behavior. Insan Media Psikologi, 12(01), 64-72. https://doi.org/10.1002/ejoc.201200111

Notoatmodjo, soekidjo. (2012). Promosi Kesehatan dan Perilaku Kesehatan. Jakarta: Rineka Cipta.

Renny. (2015). Hubungan Lama Menderita Diabetes Melitus dengan Perilkau Perawatan Kaki Secara Mandiri untuk Mencegah Ulkus Diabetikum. STIKES 
Cendekia Utama Kudus.

RISKESDAS. (2018). Hasil Utama Riset Kesehatan Dasar 2018. Kementrian Kesehatan Republik Indonesia, 1-200. https://doi.org/1 Desember 2013

Rohmatul Laili, N. (2016). Perilaku Perawatan Dalam Penerapan Edukasi Diabetes Melitus Berbasis Theory of Planned Bahaviour.

Senussi, M., Lincoln, N., \& Jeffcoate, W. (2014). Psychometric Properties of the Nottingham Assessment of Functional Footcare (NAFF). International Journal of Therapy and Rehabilitation, 18(6), 330-334.

https://doi.org/10.12968/ijtr.2011.18.6.33 0

Shaliha, T., \& Widiastri, D. (2013). Prediksi Pola Makan Sehat Remaja Melalui Theory of Planned Behaviour. Universitas Airlangga Surabaya.

Sutisna Sulaeman, E. (2017). Aplikasi Theory of Planned Behaviour pada Perilkau Pemberian ASI Ekslusif. Jurnal
Kedokteran Yasin.

Uway. (2011). Pengaruh Sikap , Norma Subjektif , Kontrol Perilaku terhadap Intensi Berperilaku Menggunakan APD pada Bidan Puskemas Cikampek, 1-14.

Whida, C. (2017). Attitude, Subjective Norms, Preceived Behavior, Entrepreneurship Education and Self-Efficacy Toward Entereneurial Intention University Student In Indonesia, 24. https://doi.org/10.1360/zd-2013-43-61064

Wigati Suprapto, S. (2017). Hubungan Sikap, Norma Subjektif, dan Persepsi Kontrol Perilaku Pengetahuan Terhadap Intensi Pelaporan Kecelakaan Kerja Perawat Rawat Inap Tulip dan Melati di Rumah Sakit X Kota Bekasi. UINi.

Windani, C., Sari, M., Haroen, H., Keperawatan, F., \& Padjadjaran, U. (2016). Effectiveness of Family Based Foot Care Education Program towards Foot Care Behavior of Type 2 Diabetes Mellitus Patients, 4. 